\title{
(-⿶凵⿴囗十)
}

Citation:

Julian, R and Schweitzer, C (2015) The origins and development of Unarmed Civilian Peacekeeping. Peace Review: a journal of social justice, 27 (1). 1 - 8. ISSN 1469-9982 DOI: https://doi.org/10.1080/10402659.2015.1000181

Link to Leeds Beckett Repository record:

https://eprints.leedsbeckett.ac.uk/id/eprint/1764/

Document Version:

Article (Accepted Version)

The aim of the Leeds Beckett Repository is to provide open access to our research, as required by funder policies and permitted by publishers and copyright law.

The Leeds Beckett repository holds a wide range of publications, each of which has been checked for copyright and the relevant embargo period has been applied by the Research Services team.

We operate on a standard take-down policy. If you are the author or publisher of an output and you would like it removed from the repository, please contact us and we will investigate on a case-by-case basis.

Each thesis in the repository has been cleared where necessary by the author for third party copyright. If you would like a thesis to be removed from the repository or believe there is an issue with copyright, please contact us on openaccess@leedsbeckett.ac.uk and we will investigate on a case-by-case basis. 


\section{The origins and development of Unarmed Civilian Peacekeeping.}

Rachel J ulian and Christine Schweitzer.

Unarmed Civilian Peacekeeping is the work of trained civilians who use nonviolence and unarmed approaches to protect other civilians from violence and the threat of violence and support local efforts to build peace. This is something which has been happening for many decades around the world, by many actors but sometimes using different terminologies. The term Unarmed Civilian Peacekeeping (UCP) describes a set of activities that civilians undertake including, but not limited to accompaniment, presence, rumour control, community security meetings, securing safe passage and monitoring. In every place where it is used around the world it is always context specific, it is adapted and developed by the people who work on the ground.

As far as terminology goes, UCP is so far a concept which remains widely unknown. The first researcher who to our knowledge used this term was Lisa Schirch in 1995 who introduced this term when she did an overview over various peace team activities on behalf of the Swedish Life \& Peace Institute. For her, the term was 'civilian peacekeeping' and she argued that many of the activities of accompaniment and interpositioning are similar in function to military peacekeeping in that they both sought to separate armed groups and deter violence. The terminology is not yet universally agreed and examples of UCP definitions are;

"UCP is a strategic mix of essential nonviolent engagement methods, principles, values and skills. Specifically trained civilians, in close coordination with local actors, apply UCP to prevent violence, consolidate peacebuilding, peacekeeping and peacemaking mechanisms as well as provide direct physical protection to civilians under threat." (Nonviolent Peaceforce \& UNITAR, 2014).

And as:

"...efforts by unarmed civilian third parties, in the field, to prevent or diminish violence by influencing or controlling potential perpetrators for the purpose of protecting people and making it safe for local people to engage in peace and justice efforts." (Furnari, 2014, p. 38)

But NGOs in the field describe their work in other ways (a list of NGOs working in this field is at the end of this article):

Peace Brigades International uses the term accompaniment and explains that they 'create space for peace', Nonviolent Peaceforce uses the term 'Unarmed Civilian Peacekeeping' and Meta Peace Team refer to their work as Third Party Nonviolent Intervention'.

In more detail:

NP website defines UCP as;

"Unarmed civilian peacekeeping (UCP) refers to the use of unarmed civilians to do 'peacekeeping'. Peacekeeping is about preventing, reducing and stopping violence...Unarmed civilian peacekeeping is a generic term that gives recognition to a wide range of activities by unarmed civilians to reduce violence and protect civilians in situations of violent conflict." (http:// www. nonviolentpeaceforce. org/ ucp accessed on March 6th 2014)

PBI website says;

"Protective accompaniment is a strategy pioneered by PBI for protecting human rights defenders and communities whose lives and work are threatened by political violence." (http:// www. peacebrigades. org/ about-pbi/ accessed on March 6 ${ }^{\text {th }}$ 2014)

Meta Peace Team; 
“MPT Teams act to reduce and prevent violence in war or conflict zones, where they are invited by one or more party to a conflict. Teams practice a specific type of conflict intervention work that MPT refers to a "Third Party Conflict Intervention" or TPNI, although there are many names for this type of action. TPNI actions include: protective accompaniment, observation/documentation, peaceful presence/ modeling peaceful behavior and reaction, and interpositioning.

(http:// www. metapeaceteam. org accessed on March $6^{\text {th }}$ 2014)

Unlike the terminology, the practice behind the term is not new at all, and has at least five sources:

1. The first was Gandhi's concept of a Peace Army (Shanti Sena) which also became known between the World Wars in Europe and was realized as a sort of community defence force by Gandhi's successor Vinoba Bhave in 1957.

2. This idea was taken up several times by Europeans (mostly in Britain) who tried (usually unsuccessfully) to build up 'peace armies' to interposition themselves in certain conflicts.

3. Related to the first have been various proposals by individuals and organisations, and directed mostly at the United Nations (since the 1990s also at the European Union), to establish a standing unarmed peacekeeping force.

4. A fourth source has been the different volunteer services that have developed since World War I seeking to contribute to reconciliation (particularly among youth) through voluntary work (Service Civil International, the various services of Christian Churches, etc.)

5. The fifth source of inspiration has of course been military peacekeeping. This is particularly true for unarmed governmental missions monitoring cease-fires.

Out of these five sources, different types of activities have been developed today that are at the core of civilian peacekeeping:

1. Different peace team organisations, with quite different approaches, methods and philosophies. At one end of the spectrum is Peace Brigades International. PBI was founded in 1981 and has specialised in nonpartisan protective accompaniment of human rights activists and been very successful in this work in many countries (Guatemala, El Salvador, Colombia, Sri Lanka, Nepal, Indonesia). At the other end are groups, often of Christian orientation, engaging in solidarity work with people they perceive as oppressed, particularly in countries in which the United States (home to most of these groups) is involved in the conflicts.

2. The 1990s saw the first larger civilian missions with protection mandates deployed by governments or international organisations: The European Community (later European Union) Monitoring Mission (ECMM) and the OSCE Kosovo Verification Mission (KVM) in the former Yugoslavia and the Truce / Peace Monitoring Group in Bougainville (see the article by Richard Gehrmann et al. in this volume) are examples, as are today's EU observers in Georgia.

3. In the last ten years relief, development (and human rights) organisations have increasingly begun to realize that humanitarian protection is a task they must take into account in their programming and work in the field.

4. The fourth has yet to come to completion: Larger-scale Unarmed Civilian Peacekeeping by nongovernmental organisations (NGOs). The NGO Nonviolent Peaceforce has (as did many earlier organisations) set itself the goal to grow to numbers that would enable it 
to deploy enough civilian peacekeepers to permit comparison to governmental peacekeeping missions, but in spite of quick progress over the last years and growing recognition by a number of governments who fund its activities, it has yet to reach this aim. And it also has been Nonviolent Peaceforce that contributed essentially to the term of "UCP" becoming known both within civil society and with governments and the United Nations (at least in the Anglo-Saxon world and recently also in Germany).

The people doing the protection, the Unarmed Civilian Peacekeeping teams, have an international component, but may include local people as well, and the teams are invited in by local people. The unarmed peacekeepers live and work with the people they are protecting. They are accessible and they learn about community mechanisms that already exist and can provide a safe space in which new committees, training or meetings can take place. UCP makes it clear to all actors, that the purpose is to stop threats of violence, that it is not trying to resolve the conflict, and that through their visibility, being known to all actors, using good communication, enabling actors to communicate and the building up of good relationships, through linking with networks and being locally based, UCP can reduce the threat of violence, protect civilians and create a space in which peaceful mechanisms can be built.

UCP is separate to other actors because it does not bring humanitarian aid nor conflict resolution solutions. By maintaining the focus on violence, asking for help from unarmed civilian peacekeepers isn't related to getting housing or aid, but it is about focusing on security, safety and the creation of mechanisms which will prevent children being abducted, will prevent retaliation attacks by controlling rumors, will ensure community leaders talk to each other to send out a message of peace, or because they request accompaniment to report human rights abuses.

UCP can be seen as an important component in our strategies for dealing with violence because building peace is a long term and complex activity, or set of activities, in which the rebuilding of relationships, trust and capacity is vital. Being able to protect civilians without the use of violence, force, or the military, demonstrates that peace is possible and helps break the cycle of violence. If we consider a model in which successful peacekeeping leads easily into long term peacebuilding (and we know that peacebuilding requires the rebuilding of relationships and ways of resolving conflict without violence), then a peacekeeping method which encompasses and models these practices and values is already helping to establish ways of working together for a time when the violence has reduced. UCP can provide a clear transition because it relies on compassion and a commitment to caring about others, and models a way of living that does not rely on violence.

The development and implementation of UCP practice is being led by NGOs who respond and innovate, and seek to embed the strategies more widely, and so we consider UCP as an external intervention strategy by NGOs working internationally, (rather than a national or domestic strategy) for preventing and reducing violence. However, there are also governmental missions practicing UCP - it is not limited to civil society alone. And there are, of course, examples of nationally led organisations managing their own activities to prevent and reduce violence, but this is a far less visible and barely studied component of UCP.

Based on the public texts on websites used by the NGOs represented in this journal, there are some common values they share:

1. All nine organisations in this study are clear they are nonviolent in principle, mandate and implementation.

2. Most (including Peace Brigades International-PBI, Nonviolent Peaceforce-NP, Meta Peace Team -MPT, and Christian Peacemaker Teams-CPT) said they were invited by local people, 
and Operation Dove, MPT, NP and PBI explicitly said that they lived and worked with the people they protect.

For example, Meta Peace Team described their work as;

"Unlike conflict resolution/transformation, mediation or dialogue work, we do not seek to mediate or resolve the underlying conflict directly, or to broker 'peace talks'-although we may act to support one or all of these actions.

Instead, our Teams are focused on the front-line work of reducing violence and the threat of violence, in order to create some safe(r) space for everyone involved. Creating this space can then allow the parties themselves to determine the means and the terms of transforming/ resolving the conflict." (www. metapeaceteam.org)

And PBI say;

"We believe that lasting transformation of conflicts cannot be imposed from outside, but must be based on the capacity and desires of local people. Therefore we do not take part in the work of the organisations we accompany. Rather our role is to open political space and provide moral support for local activists to carry out their work without fear of repression." http:// www. peacebrigades. org/ about-pbi/ accessed on March $6^{\text {th }}$ 2014)

From understanding that there are shared values in all these chosen NGOs, we can locate them all as UCP practitioners.

Non-interference and non-partisanship were explicit values in NP, PBI and Ecumenical Accompaniment Project in Palestine and Israel -EAPPI and these values are often cited as a component of peacekeeping in general. There is significant debate on the role of impartiality and what it means in practice, because all the NGOs operating explained, in their aim, vision or activity description that they protect people and their human rights, and some, including Witness for Peace -WfP, CPT, Swedish Fellowship of ReconciliationSweFOR and Operation Dove include direct action and campaigning to support people experiencing oppression or change policies.

All these organisations work directly on the ground, they find, train and send people to work, live and act alongside those experiencing violence. Their work on the ground varies but all the organisations use accompaniment and presence. Ellen Furnari's research indicates that peacekeepers see this as a core activity and all see presence and relationship building as one of their main tools, whether armed or unarmed. Some of the different ways they explain what they do are EAPPI says 'protective presence' and 'monitoring human rights abuses' (http:// eappi.org/ en), MPT explains "TPNI actions include: protective accompaniment, observation/ documentation, peaceful presence/ modelling peaceful behaviour and reaction, and interpositioning"

((www. metapeaceteam. org). Dove list activities they do as "physical interposition, complaint of human rights violations, accompaniment of refugees or menaced people; actions of a concrete solidarity, supporting the meeting and mediating between the fighting parts, protection the minorities, animation with children"

(http:// www. operationdove.org) . NP says: "Our activities have ranged from entering active conflict zones to remove civilians in the crossfire to providing opposing factions a safe space to negotiate. Other activities include serving as a communication link between warring factions, securing safe temporary housing for civilians displaced by war, providing violence prevention measures during elections and negotiating the return of kidnapped family members." (nonviolentpeaceforce.org) And PBI say "The central focus of PBI's work is that of international presence defined as one or more of the following: physical presence, physical accompaniment, public relations, networking, observing, reporting, and building international support networks." (http:// www. peacebrigades. org) Some of them also carry out advocacy work outside of the affected country in order to influence political systems to reduce violence (for EAPPI, it is awareness raising activity, whilst WfP seek to change government policy). 
In order to consider what impact this work has, a comparative analysis by J ulian and Furnari shows that in projects in NP, projects have a local level impact within 2 years, but that it takes longer to become more established and have a larger, more strategic, impact.

CPT describe the difference they make as;

"We know that we have prevented deaths and deterred violence because we have stopped armed groups from acting. We know that the people with whom we work tell us they are safer because of our presence and work. We know that CPT's work has expanded the "space" for local peacemakers to pursue their already-inspiring peace work." (http:/ / www.cpt.org)

PBI give a comprehensive view of the impact of their work in a year to show the extent of their work and NP includes evaluations from some of their projects.

Our review of organisations indicate it is a relatively stable field. The organisations that set up to carry out a project or support an area, remain committed and involved for long periods of time, often 10 or more years. Although there are not many organisations, they are well established and all of them have closed and started various projects over the life of their organization, giving them a track record. NP is the newest organisation to be established and they are now 12 years old. The international mission of the Truce/ Peace Monitoring Team in Bougainville was comparatively short-lived, lasting only about six years, from 1997 to 2003.

There is an emerging coherence and core values in this emerging field of Unarmed Civilian Peacekeeping, however there is no evidence of a shared analytical framework or collaboration between the organisations (except in Colombia where several organisations work in the same geographical area), which suggests that future development in this field may benefit from pooling knowledge to further improve the impact of their efforts and benefit from opportunities explored in the articles in this issue.

We would like to highlight an area within which UCP challenges the way we deal with violent responses to conflict on a strategic level.

UCP approaches challenge the mainstream ideas on peacekeeping. We currently understand peacekeeping to be an action almost wholly carried out through the UN and involving the military, and that for peacekeeping to be effectively carried out, we assume it must include the use of force and weapons. In fact peacekeeping is one of the three components of building a sustainable peace that most interventions are based around, those of peacemaking, peacebuilding and peacekeeping. We agree that peacemaking and peacebuilding are carried out by multiple actors at many levels, for example peacemaking usually involves international negotiation, but may also involve village dialogue projects. Peacebuilding has had wide ranging input on the different mechanisms of building the state, rebuilding trust and creating peaceful norms, by Internationals Organisations, NGOs and Community Based Organisations. UCP gives us a mechanism and format and evidence that peacekeeping can equally be done by civilians and NGOs and does not need the military. But to bring that dialogue into the light, taking that dominant role away from UN Department of Peacekeeping Operations and the military will be no easy task and as the need for large militaries have reduced since the Cold War, we have seen NATO and others redefining their role as neccessary for maintaining the peace, so to argue that they are not neccessary for this is a struggle.

UCP helps us understand and challenge the way we think of security for ourselves and others. 
In this special issue we have brought together examples of Unarmed Civilian Peacekeeping in practice, some theoretical work about how we understand the impact and need for UCP, and articles which consider how the field might develop and the challenges it faces.

There are two NGO case studies, from Mindanao and South Sudan which demonstrate the activities and context within which UCP operates, written by Georgi Engelbrecht and Vidushi Kaushik who worked with Nonviolent Peaceforce in Mindanao and Tiffany Easthom, the Director of the South Sudan project.

Richard Gehrmann and colleagues give an account of an earlier governmental unarmed intervention in Bougainville which helps to show a breadth of experience in this field.

Enrique Eguren, a founder of Peace Brigades International explains how a deeper understanding of 'space' helps us understand the impact of how providing a presence means a greater space for peace, in different ways.

Ellen Furnari has shown how that 'presence' is an essential component of peacekeeping, whichever actor is doing the task, and Tim Wallis considers how visibility, sometimes achieved through 'presence' can be a factor in understanding why people choose to reduce and halt violence and shows how this is employed in UCP.

Alessandro Rossi considers how Inter-governmental actors relate to the principles of Unarmed Civilian Peacekeeping.

The articles in this issue span a wide breadth of issues that show the strengths, opportunities and challenges for unarmed civilian peacekeeping, but the development of the field can be seem as one in which practice and theory are increasingly brought closer together and a deeper understanding of both the short term and long term impact of UCP. In bringing these articles together it is clear that many research questions remain and the potential for development is great.

The NGOs we include in this issue are:

Peace Brigades International (PBI) who have been working in this field for 30 years. Their largest project is in Colombia. www. peacebrigades.org

Nonviolent Peaceforce (NP) has been working for 12 years and their largest projects are in Mindanao (Philippines) and in South Sudan. www. nonviolentpeaceforce.org

Meta Peace Team (MPT) previously known as Michigan Peace Team, has been working for 16 years. They now work in West Bank, Palestine/ Israel. www. metapeaceteam. org

Witness for Peace (WfP) started in 1983/ 84 by accompanying people in Nicaragua and advocating back home against the US support for the guerilla fighting the new Nicaraguan government, and now works across Latin America. www. witnessforpeace. org

Ecumenical Accompaniment Programme in Palestine and Israel (EAPPI) has been working in Israel and Palestine since 2002 and volunteers stay for a few months. http:// eappi. org/ en

Operation Dove started in 1995 work in Israel and Palestine, Albania and Colombia. www. operationdove.org

Fellowship of Reconciliation USA (FoRUSA) has been accompanying peace communities in Colombia since 2002. http:// forusa. org/ content/ colombia-peace-update

Swedish FoR (SweFOR) have peace observers in Colombia, Guatemala and Mexico. http:// krf.se/ en/

Christian Peacemakers Team (CPT) work in six projects and have both long term and short term corps. www.cpt.org 
Recommended reading.

Büttner, Christian W. (1995) Friedensbrigaden: Zivile Konfliktbearbeitung mit gewaltfreien Methoden. Münster: Lit Verlag

Coy, Patrick G. (1997) Protecting Human Rights: The Dynamics of International Nonviolent Accompaniment by Peace Brigades International in Sri Lanka. UMI Dissertation Services

Furnari, Ellen (2014) Understanding effectiveness in peacekeeping operations: Exploring the perspectives of frontline peacekeepers. Dissertation

J ulian, R and Furnari, E. (2014) Comparative study of Unarmed Civilian Peacekeeping: contexts, processes and impacts. Online at

https:/ / www. academia.edu/ 9633407/ Comparative_analysis_Unarmed_Civilian_Peacek eeping

Inter-Agency Standing Committee (2002) Growing the Sheltering Tree - Protecting Rights Through Humanitarian Action. PDF/ Web version. [Online] at http:// www.icva.ch/ doc00000717.html [25.8.2009]. Geneva: UNICEF

International Committee of the Red Cross (2008) Enhancing Protection for Civilians in Armed Conflict and Other Situations of Violence. [Online] at

বhttp:/ / www.icrc.org/ Web/ Eng/ siteeng0. nsf/ htmlall/ section_publications_protection? OpenDocument $>$ (25.8.2009)

Mahony, Liam (2006) Proactive Presence. Field Strategies For Civilian Protection. Geneva: Henry Dunant Centre for Humanitarian Dialogue. [Online] at বttp:/ / www. hdcentre. org/ publications/ > [10.9.2008]

Mahony, Liam and Eguren, Luis Enrique (1997) Unarmed Bodyguards. International Accompaniment for the Protection of Human Rights. West Hartford:Kumarian Press * deutsch: Gewaltfrei stören - Gewalt Verhindern. Rotpunktverlag, Zürich 2002

Moser-Puangsuwan, Yeshua and Weber, Thomas (Hrsg.) (2000) Nonviolent Intervention Across Borders. A RecurrentVision. Honolulu: Spark M. Matsunaga Institute for Peace

Müller, Barbara (2004) The Balkan Peace Team 1994-2001. Nonviolent Intervention in Crisis Areas with the Deployment of Volunteer Teams. Stuttgart: ibidem Verlag

Schirch, Lisa (2006) Civilian Peacekeeping. Preventing Violence and Making Space for Democracy. Uppsala: Life and Peace Institute

Schweitzer, Christine (Hrsg.) (2010) Civilian Peacekeeping - A Barely Tapped

Ressource. Arbeitspapier Nr. 23, Institute for Peace Work and Nonviolent Conflict

Transformation. Vehrte: Sozio-Publishing. [Online] at

http:// www.ifgk. de/ oben/ publikationen all8.htm

Schweitzer, Christine, Howard, Donna, J unge, Mareike, Levine, Corey, Stieren, Carl and Wallis, Tim (2001) Nonviolent Peaceforce Feasibility Study. Minneapolis. [Online] at বhttp:// www. nonviolentpeaceforce. org/ en/ feasibilitystudy> [2.3.2009]

Slim, Hugo and Eguren, Luis Enrique (2004) Humanitarian Protection. A Guidance Booklet. Pilot Version, ALNAP, [online] at বhttp:// www. alnap.org/ alnappubs. html> [30.11.2005] 